\title{
The Right to Education for Migrant Children in Light of the Latest General Comments by the UN Treaty Bodies
}

\author{
Ekaterina V. KISELEVA \\ Department of Public International Law \\ Peoples' Friendship University of Russia (RUDN \\ University) \\ Moscow, Russia \\ kiseleva_ev@rudn.university
}

\author{
Maria N. OSIPOVA \\ Department of Public International Law \\ Peoples' Friendship University of Russia (RUDN \\ University) \\ Moscow, Russia
}

\author{
Natalia EMELIANOVA \\ Department of Public International Law \\ Peoples' Friendship University of Russia (RUDN University) \\ Moscow, Russia
}

\begin{abstract}
The right to education has a fundamental importance for children in migration context. Besides its general value, realization of the right to education is a prerequisite sine qua non for successful integration of migrant children into the host society. This article touches upon the right to education of migrant children in the context of activity of the Committee on the Protection of the Rights of All Migrant Workers and Members of Their Families, that has produced four general comments, each having provisions of the right of education. The paper reveals that the significance of the mentioned Committee's work is being strengthened and supported by means of basing the conclusions of this treaty body on the outcomes of other treaty bodies that have wider participation of States. The two joint general comments adopted in November, 2017, by the Committee on the Rights of the Child and the Committee on the Protection of the Rights of All Migrant Workers and Members of Their Families, on human rights of migrant children are taken as the most recent examples.
\end{abstract}

Keywords-International law; Migration; Human rights; Right to education; Children'S rights; Migrant children

\section{INTRODUCTION}

The complex nature of human rights appears in different forms and in many respects, in particular, in the activities of the United Nations (hereinafter UN) treaty bodies system for human rights protection [1]. The treaties, on basis of which the corresponding bodies are established have a different level of participation by states, however the tendency is to have many points of intersection where a range of the treaty bodies express their views. One of such cross-points is the right to education. This article is focused on the right to education belonging to a specific and especially vulnerable group of individuals migrant children, for whom the right to education is crucial in terms of integration and of prospects for further development of all kinds. The right to education is, thus, the object of the three treaty body's attention, them being the Committee on Economic, Social and Cultural Rights, the Committee on the Rights of the Child and the Committee on the Protection of the Rights of All Migrant Workers and Members of Their Families Analysis of the general comments issues by the Committee on the Protection of the Rights of All Migrant Workers and Members of Their Families (hereinafter the Committee on Migrant Workers or Committee on the Rights of Migrants), including the two joint general comments on human rights of children in the context of the international migration dated November 16, 2017, [2; 3] show that the positions of each treaty body is based on and strengthened by the mutual reliance.

Such joint acts of human rights treaty bodies are remarkable not only as a rare practice in the human rights sphere at the universal level, but also due to the fact that not all member states of the UN are parties to both corresponding international human rights treaties that form the legal basis for the work of the above mentioned Committees. All member states of the UN joined the Convention on the Rights of the Child, 1989, except the USA; though the International Convention on the Protection of the Rights of All Migrant Workers and Members of Their Families, 1990, was ratified by only 51 states which, with the exception of Argentina, are states of origin of migrants, but not states of destination and employment of migrant workers and members of their families.

The analysis of the above mentioned two joint general comments concerning human rights of children in the context of the international migration from practical point of view is useful to all countries that have undertaken obligations to ensure the right to education for children without any exceptions and in any situation including in relation to migrant children, but not joined the Convention on the Protection of the 
Rights of All Migrant Workers and Members of Their Families, 1990.

\section{THE RIGHT TO EDUCATION}

The right to education has been affirmed in the Universal Declaration of Human Rights, 1948, which proclaimed: "Everyone has the right to education. Education shall be free, at least in the elementary and fundamental stages. Elementary education shall be compulsory." (p.1 Art. 26) [4].

The provisions of the Universal Declaration have gained traction in the International Convention on the Elimination of All Forms of Racial Discrimination, 1966 ((e) "v" Art. 5), the International Covenant on Economic, Social and Cultural Rights, 1966 (Art. 13-14), the Convention on the Elimination of All Forms of Discrimination against Women, 1979 (Art. 10), the Convention on the Rights of the Child, 1989 (Art. 28-29), the Convention on the Rights of Persons with Disabilities, 2006 (Art. 24). In respect of a migration situation, the right to education is codified in Art. 30 and 43 of the International Convention on the Protection of the Rights of All Migrant Workers and Members of Their Families, 1990. Though many states participate in all or the majority of the above mentioned international treaties, except the last one, analysis of the provisions of the International Convention on the Protection of the Rights of All Migrant Workers and Members of Their Families, 1990, can give the deepest answer to a question of the content and scope of international legal obligations concerning the right to education of migrant children.

Article 30 of the International Convention on the Protection of the Rights of All Migrant Workers and Members of Their Families, 1990, states that "Each child of a migrant worker shall have the basic right of access to education on the basis of equality of treatment with nationals of the State concerned. Access to public pre-school educational institutions or schools shall not be refused or limited by reason of the irregular situation with respect to stay or employment of either parent or by reason of the irregularity of the child's stay in the State of employment." This article is located in part III of the Convention which extends to all migrants, irrespective to complying with all rules of law of the state of employment (receiving state).

\section{GENERAL COMMENTS}

\section{A. General comments of the Committee on the Protection of the Rights of All Migrant Workers and Members of Their Families}

Provisions of Art. 30 of the above mentioned Convention have found reflection in each of the four, adopted up to May 25, 2018, general comments of the Committee on Migrant Workers. The general comment No. 1 on migrant domestic workers dated February 23, 2011, notes that "the risk of abuse ... for child domestic workers, who make up a significant proportion of domestic workers. Their young age, isolation and separation from their families and peers, and near-total dependence on their employers exacerbate their vulnerability to violations of their rights under the Convention, including the basic right of access to education." (para. 14). Paragraphs 57 and 59 of the same document contain the recommendations of the Committee to the states to "ensure that all migrant children, independently of their migration status, have access to free and compulsory primary education as well as to secondary education on the basis of equality of treatment with nationals of the State concerned (article 30), and that the domestic work carried out by children does not interfere with their education. Schools should not be required to report data on the regular or irregular status of pupils to immigration authorities" (para. 57) and "eliminate discriminatory policies and practices that deny or restrict the rights of children of migrant domestic workers, notably their right to health and education (articles 28 and 30)" (para. 59).

General comment No. 2 on the rights of migrant workers in an irregular situation and members of their families in para.7579 in detail discloses the right to education concerning illegal migration [5]. With reference to the International Covenant on Economic, Social and Cultural Rights, Committee on the Rights of Migrants emphasizes that "States parties must provide free and compulsory primary education for all, including children of migrant workers, regardless of their migration status. As such, States parties have an obligation to eliminate all direct costs of schooling, such as school fees, as well as alleviate the adverse impact of indirect costs, such as expenses for school materials and uniforms. Access to secondary education by children of migrant workers must be ensured on the basis of equality of treatment with nationals. Accordingly, whenever children who are nationals have access to free secondary education, States parties must ensure equal access by children of migrant workers, irrespective of their migration status. Similarly, when States parties provide different forms of secondary education, including vocational education, they should also make them accessible to children of migrant workers. The same principle applies to free preschool education or to scholarship schemes. Therefore, whenever children who are nationals have access to free preschool education or scholarships, States parties must ensure equal access by children of migrant workers, irrespective of their migration status." (para. 75). Further the Committee pays attention to obligations of the states for protection of migrant children from discrimination in their educational systems (para. 76) and elaborates on that "States parties shall not require schools to report or share data on the regular or irregular status of pupils or their parents to immigration authorities or conduct immigration enforcement operations on or near school premises, as this would limit access to education by children of migrant workers" (para. 77). In the following paragraph of the general comment the Committee focuses attention that "the obligation of the State of employment to endeavour to facilitate the teaching of the mother tongue and culture is explicitly accorded to the children of migrant workers in a regular situation pursuant to article 45, paragraph 3 , of the Convention" and emphasizes that "the right to respect for one's cultural identity (art. 31) belongs to all migrant workers and members of their families, including children. Considering these two provisions together, along with article 29, paragraph 1 (c), of the Convention on the Rights of the Child, which applies to all children, the Committee is of the view that States parties should also ensure access for children of migrant workers in an irregular situation to mother-tongue instruction if 
already available to children of migrant workers who are documented as having the same mother tongue" (para. 78). In the last paragraph of the document the Committee coordinates obligations to register the birth of children to the right to education (para. 79).

B. Joint general comments of the Committee on the Protection of the Rights of All Migrant Workers and Members of Their Families and of the Committee on the Rights of the Child

Complex and systematic interpretation of standards of international treaties is even more brightly shown in general comments No. 3 and 4 adopted by the Committee on the Rights of Migrants together with the Committee on the Rights of the Child. We shall remind that whereas the Convention on the Rights of Migrants, 1990, has the lowest level of ratification among all main universal international treaties on human rights (51 states on the date of May 25, 2018), the Convention on the Rights of the Child in this sense is characterized exactly in the opposite way - it was ratified by almost all states. In this regard Committees have considered it important to emphasize interrelation of two general comments among themselves (in the footnote to the title of each document) and the provision that "while the present comment is based on the provisions of both Conventions, it is important to underline that the human rights norms clarified herein are built on the provisions and principles of the Convention on the Rights of the Child. Therefore, the authoritative guidance contained in the present joint general comment is equally applicable to all States parties to the Convention on the Rights of the Child and/or the International Convention on the Protection of the Rights of All Migrant Workers and Members of Their Families." (para. 4 Joint general comment No. 3).

On the substance of the considered right to education concerning migrant children three aspects of the third general comment should be noted. The first one. In para. 5 "the increasing attention that both Committees have given to the rights of children in the context of international migration" is specified as background information, on the basis of "other United Nations resolutions and reports, various outputs of the United Nations human rights mechanisms and United Nations, intergovernmental and civil society initiatives relating to children in the context of international migration, including: (a)the statement by the Committee on Economic, Social and Cultural Rights on the duties of States towards refugees and migrants under the International Covenant on Economic, Social and Cultural Rights (E/C.12/2017/1), in which the Committee recalled in particular that "protection from discrimination cannot be made conditional upon an individual having a regular status in the host country", and also recalled that "all children within a State, including those with an undocumented status, had a right to receive education and access to adequate food and affordable health care" (para. 6). The second one. General measures on implementation of each of the conventions as demanding to include in the policies and practices ... (a) comprehensive, inter-institutional policies between child protection and welfare authorities and other key bodies, including on ... education" (para. 18). And the third one. In relation to the content of the right to life, survival and development Committees have noted "obstacles children may face in gaining access to education... can negatively affect the physical, mental, spiritual, moral and social development of migrant children and children of migrants" (para.40).

The latest general comment (No. 4 for the Committee on the Protection of the Rights of All Migrant Workers) of the two Committees contains the whole section on the right to education and vocational training (para. 59-63). The main contents of the section can be consolidated to the following. Para. 59, in the beginning repeating the provisions of Art. 30 of the Convention on the Rights of Migrants, 1990, that "all children in the context of international migration, irrespective of status, shall have full access to all levels and all aspects of education, including early childhood education and vocational training, on the basis of equality with nationals of the country where those children are living", clarifies that "this obligation implies that States should ensure equal access to quality and inclusive education for all migrant children, irrespective of their migration status. Migrant children should have access to alternative learning programmes where necessary and participate fully in examinations and receive certification of their studies."

In para. 60 the Committees strongly "urge States to expeditiously reform regulations and practices that prevent migrant children, in particular undocumented children, from registering at schools and educational institutions" and also repeat the contents of para. 77 of the General comment of Committee on the Rights of Migrants No. 2 on incompatibility of checks of migration regime in different forms with the sphere of education, "while access to upper-level education is not compulsory, the principle of non-discrimination obliges States to provide available services to every child without discrimination on the basis of their migration status or other prohibited grounds."

Further the Committees recommend to the states "to recognize the child's former education by acknowledging previously obtained school certificates and/or issuing new certification based on the child's capacities and capabilities, to avoid creating stigmatization or penalization" (para. 60), and repeating the provisions of general comments of Committee on the Rights of Migrants No. 1 and 2 - oblige the states "to eliminate any discrimination against migrant children" and, besides, "to adopt appropriate and gender-sensitive provisions to overcome educational barriers" (para. 62).

In the context of development of international law concerning migration in general especially remarkable aspect to Russia is an explanation to the last quoted provision: "This means that, where necessary, targeted measures are needed, including additional language education [reference to the Art. 45 of the International convention on the Protection of the Rights of All Migrant Workers and Members of Their Families], additional staff and other intercultural support, without discrimination of any kind. States are encouraged to dedicate staff to facilitating access to education for migrant children and to promoting the integration of migrant children into schools. In addition, States should take measures aimed at prohibiting and preventing any kind of educational segregation, to ensure that migrant children learn the new language as a 
means for effective integration. State efforts should include the provision of early childhood education as well as psychosocial support. States should also provide formal and non-formal learning opportunities, teacher training and life skills classes." (para. 62). It is hardly possible to find treaty rules of international law concerning integration of migrants. Such rules are proclaimed with the words of the last paragraph on education of the general comment No. 4: "States should develop concrete measures to foster intercultural dialogue between migrant and host communities and to address and prevent xenophobia or any type of discrimination or related intolerance against migrant children. In addition, integrating human rights education, including on non-discrimination, as well as migration and migrants' rights and children's rights, within education curricula would contribute to preventing in xenophobic or any form of discriminatory attitudes that could affect migrants' integration in the long term." (para. 63).

\section{CONCLUSION}

Detailed analysis of the interpretation given to the provisions of the International Convention on the Protection of the Rights of All Migrant Workers and Members of Their Families, 1990, in the general comments by the Committee on the Protection of the Rights of All Migrant Workers and Members of Their Families leads to a conclusion relevant not only to the content of the right to education of migrant children, but also to the way of imposing obligations on the third states (in the meaning of the Vienna Convention on the Law of Treaties, 1969). The presented quotations from the general comments by the Committee on the Protection of the Rights of All Migrant Workers and Members of Their Families demonstrate that the UN treaty bodies erase minor details in understanding of formulation of separate human rights existing between various international human rights treaties, thus, pushing the States to follow and implement complex and systematic interpretation of the relevant international legal obligations. The Committees achieve this result by, firstly, issuing joint general comments on treaties with different degree of ratification. Secondly, by motivating the specific interpretation of a less ratified treaty by the provisions of the more ratified treaty and by giving the same provisions when interpreting the more ratified treaty. And, thirdly, by confirming the aspects that had been disclosed in relation to a less ratified convention in the interpretation linked to more ratified treaties.

\section{REFERENCES}

[1] A.Kh. Abashidze, A.E. Koneva, UN Treaty Bodies on Human Rights: Manual, 2nd ed., Moscow: RUDN, 2015.

[2] Joint general comment No. 3 (2017) of the Committee on the Protection of the Rights of All Migrant Workers and Members of Their Families and No. 22 (2017) of the Committee on the Rights of the Child on the general principles regarding the human rights of children in the context of international migration // CMW/C/GC/3-CRC/C/GC/22.

[3] Joint general comment No. 4 (2017) of the Committee on the Protection of the Rights of All Migrant Workers and Members of Their Families and No. 23 (2017) of the Committee on the Rights of the Child on State obligations regarding the human rights of children in the context of international migration in countries of origin, transit, destination and return // CMW/C/GC/4-CRC/C/GC/23.

[4] Universal Declaration of Human Rights, 1948. UN Doc A/RES/217(III).

[5] E.V. Kiseleva, M.N. Osipova, "Human rights approach to migration on the example of realization problems of the right to education by irregular migrant children in the Russian Federation," Probely v rossijskom zakonodatel'stve, No. 8, pp. 374-379, 2016. 